\title{
Roberto González Echevarría
}

\author{
Yale University \\ New Haven - CO, Estados Unidos
}

\begin{abstract}
Resumo
Visão panorâmica da correspondência de vinte e quatro anos entre Roberto González Echevarría e Severo Sarduy, que analisa a relação do escritor cubano com o grupo Tel Quel e a literatura latino-americana. Conclui-se que Sarduy, ainda que influenciado, em uma primeira etapa, pela teoria francesa, foi derivando para temas latino-americanos, especificamente, cubanos, em grande parte devido à influencia de José Lezama Lima. As cartas analisadas revelam essa tendência, assim como a incorporação gradual do barroco como modelo na sua literatura. Em última instância, o valor dessa produção reside nas características propriamente literárias, nos argumentos, nas personagens, especialmente estes últimos, dentre os quais se destacam os travestis.
\end{abstract}

Palavras-chave: Literatura epistolar, relação entre autor e crítico, Severo Sarduy.

\section{Resumen}

Visión panorámica de la correspondencia de veinticuatro ańos entre Roberto González Echevarría y Severo Sarduy, que analiza la relación del escritor cubano con el grupo Tel Quel y la Literatura Latinoamericana. Se concluye que Sarduy, aunque influido al principio por la teoría francesa, fue derivando hacia temas latinoamericanos, específicamente cubanos, en parte debido a la influencia de José Lezama Lima. Las cartas analizadas revelan esta tendencia, y la incorporación gradual del barroco como modelo de su literatura. En última instancia el valor de ésta reside en sus características literarias, argumentos, personajes, especialmente estos últimos entre los que se destacan los travestís.

\section{Abstract}

A panoramic overview of the twenty-four year correspondence between Roberto González Echevarría and Severo Sarduy, which analyzes the relationship of the Cuban author with the Tel Quel group and Latin American literature. The conclusion is that, though influenced at the beginning by French theory, Sarduy derived toward Latin American topics, specifically Cuban ones, partly due to the influence of José Lezama Lima. The letters studied reveal this tendency, as well as the gradual incorporation of the Baroque as a model for his literary production. In the end, the value of Sarduy's work resides in its literary qualities, such as plots and characters, particularly transvestites among the latter, not the theory.

\footnotetext{
${ }^{1}$ Texto da conferência de abertura do IV Coloquio Literatura y Margen. Severo Sarduy, proferida no dia 27 de outubro de 2016 na Sede da Reitoria da Universidad Nacional de Tres de Febrero (UTREF), Buenos Aires, Argentina, um evento promovido pelo Programa de Estudios Latinoamericanos Contemporáneos y Comparados dessa institução.
} 
Palabras claves: Literatura epistolar, relación entre autor y crítico, Severo Sarduy.
Keywords: Epistolary literature, relationship between author and critic, Severo Sarduy.

Minha conferência de hoje vai ser tanto testemunhal quanto analítica e pretende chegar a uma síntese do que escrevi sobre Severo Sarduy, e do que penso, em última instância, sobre sua obra. Não posso supor que todos vocês leram meus textos, mas os que o fizeram reconhecerão algumas ideias que já havia apresentado antes. Vou tratar de refiná-las aqui e ir mais adiante. O texto que apresento é um esboço daquele que eu desejaria que pudesse chegar a ser o prólogo de um volume que reunisse as cartas que Severo Sarduy me escreveu ao longo de vinte e quatro anos. Foram muitas, como vocês poderão ver. (Encontrar na caixa de correio uma "carta de Severo" era, para mim, recordando Lezama, "uma festa inominável”, daí meu título.) Outro esclarecimento: desculpem-me, mas a partir de agora vou dizer Severo, não "Sarduy" ou "Severo Sarduy", porque, como devem saber, fomos muito amigos e soa falso ou solene referir-me assim a ele. Com isso, não quero sugerir informalidade ou falta de respeito em minha aproximação à sua obra. Severo e eu nos falávamos e nos escrevíamos com familiaridade, e até com certo "cubaneo", sem deixar de ser sérios no que nos dizíamos. Precisamente por nossa intimidade, pretendíamos ser profundos, tanto intelectual como afetivamente. A confiança entre nós nos permitia prescindir da retórica, ou acreditar que o fazíamos, e chegar ao nível da confissão, como se ninguém nos estivesse ouvindo e pudéssemos acessar todos os registros do idioma, sem poses ou presunçóes, nem vergonha pelos cubanismos, barbarismos, galicismos e anglicismos. O que acabo de dizer não é algo simples e vou examiná-lo a seguir.

Devo advertir também que a ideia principal de minha conferência, que provavelmente não vai ser do agrado de alguns de vocês, é que a dimensão mais valiosa e perdurável da obra de Severo é a literária, não exatamente a teórica: os argumentos; os personagens; o estilo e o tom; sua reciclagem de ideias e figuras latino-americanas, mais especificamente cubanas; o mundo fictício que cria e adquire uma coerência interna reconhecível, que ele mesmo assume como próprio, repete de maneira premeditada e reflete. Reaparecem, por exemplo, Auxilio e Socorro em Pájaros de la playa. Reconhecemos em Severo matronas melancólicas ou desesperadas pela deterioração ou imperfeição de seus corpos que apelam ao masoquismo para remediá-los, personagens com duplos correlativos que só existem em relação a eles, machos bemdotados adorados por outros, tipos exuberantemente maquiados, com disfarces 
ridículos, e um ambiente deliberadamente artificial, onde nunca aparece o natural, em nenhum sentido da palavra. E existem, especialmente, travestis, cujo sexo de origem nunca se sabe com certeza qual é; o que os define é o exagerado simulacro de sua sexualidade aparente. Abunda em Severo a sensação de que toda a armação que ele cria está sustentada na simulação, na falsidade, no teatral, no postiço, no recente, sempre ameaçando vir abaixo a qualquer momento. $\mathrm{O}$ barroco reside na impressáo de fugacidade absoluta que impera, inclusive do narrador ou dos narradores, que falam do interior do texto com sotaque rebuscado, alambicado, que se sabe assim e faz alarde disso. Tudo isso constitui a assinatura de Severo e é o que o faz autor. É tão reconhecível como uma página de Proust ou de Lezama. Severo mesmo foi derivando para o convencimento de que isso era o que havia de mais valioso em seu trabalho, o que ia perdurar. Lezama desempenha um papel decisivo nessa tomada de consciência.

Aquilo que Severo pode ter trazido para a teoria de seu momento - da qual penso que fez, no melhor dos casos, uma paródia crítica resgatável - não permaneceu nem teve as repercussōes que, sem dúvida, ele esperou que tivesse. Por exemplo, Barroco é de 1974 e, entretanto, Octavio Paz não menciona Severo nem uma vez em seu Sor Juana Inés da Cruz o las trampas de la fe, que é de 1982. Sor Juana foi o último grande poeta barroco e o livro inclui uma ampla bibliografia, em que até figuram meus ensaios. Paz publicou Severo repetidas vezes em suas revistas e se consideravam amigos, cúmplices (voltarei a isso mais tarde). De Escrito sobre un cuerpo e La simulación permanecem, sim, ecos temáticos em escritores posteriores recentes como Fernando Vallejo e Mario Bellatín, e obviamente na crítica especializada, mas nada na França nem no mundo de fala inglesa, que eu saiba, onde não é conhecido, além dos departamentos universitários de espanhol. Na América Latina, Severo pertence ao cânone, mas por causa de suas obras de ficção e pelas características de sua escritura mencionadas acima. Seu emblema é o travesti, seu assunto definidor, o homossexualismo, o qual não é de todo correto, se o associamos a isso que se tornou o movimento gay, que náo interessava a Severo porque o que ele valorizava era o transgressivo de sua sexualidade, náo que esta fosse aceita como inócua alternativa de comportamento erótico. Sua obsessão eram as variantes estruturadas, correlativas e sistemáticas, da atuação (valha a palavra) sexual, motivadas pelo desejo, cuja última razão de ser é o medo da morte, o terror do vazio, que é o que aparece em seus romances e ensaios - um tema universal e atemporal. De outra maneira, Severo seria um ingênuo a mais sobre o tema gay e seus lugares-comuns.

Ignoramos, por certo, nesta reuniáo, um dos dogmas do meio crítico em que se desenvolveu Severo, a tão mencionada "morte do autor". Dedicamonos aqui, pelo contrário, à vida de Severo e náo gostaríamos que ele morresse 
outra vez. Desejamos que siga vivo para nós e para a literatura. O clichê da morte do autor foi uma impostura. Para começar, Michel Foucault e Roland Barthes, seus principais inspiradores, alardeavam sua condição de autores, que levavam por todo o mundo e proclamavam em e desde Paris, foco irradiador de hegemonia intelectual na época. Sua autoridade como autores era indiscutível. O mesmo ocorre com os outros, como Derrida, Lacan, Sollers e Kristeva; todos eles, com exceção de Foucault, terminaram sendo, ademais, autores de obras literárias, apesar do que disseram em algum momento de suas carreiras contra isso. Eu vivi em Paris a prática dessa hipocrisia intelectual. Pós-estruturalistas loucos para assistir um seminário de Lacan, ou a uma conferência de Derrida, e de figurar em Tel Quel ou Communications. Nenhum queria estar morto, nem em sentido literal, nem figurado.

É revelador, pensando no peso das modas literárias, que a tal morte do autor só tivesse sentido no contexto da crítica francesa, a qual, ainda a princípios dos anos sessenta do século passado, era reacionária e acadêmica no pior sentido (tinha virtudes, como a explication de texte, que se praticava desde a escola). Mas isso não era assim no mundo de língua espanhola, onde havíamos passado por uma estilística na qual o ponto de partida havia sido Ferdinand de Saussure, de cujo Cours de linguistique générale (Curso de linguistica geral) havia sido publicado nesta mesma cidade de Buenos Aires, em 1945, uma magnífica tradução com prólogo e notas de nada menos que Amado Alonso. Nem tampouco na crítica de língua inglesa, na qual contávamos com o decisivo ensaio de William Wimsatt intitulado "The Intentional Fallacy", que primeiro apareceu em 1946, e que havia demolido a crítica que partia da suposta intenção do autor, derivada de sua biografia. Ninguém se atrevia a fazer estudos convencionais de "vida e obra" em inglês, ou só de soslaio, com uma discreta reverência a Wimsatt. Na França, pelo contrário, ainda reinavam os discípulos de Gustave Lanson (1857-1934), e quando Barthes publicou Sur Racine, em 1963, um incomodado Raymond Picard respondeu com seu Nouvelle critique ou nouvelle imposture, em 1965. A polêmica continuou e os estruturalistas ganharam com uma magnífica goleada. De qualquer forma, o ímpeto da moda é tal que tanto em espanhol quanto em inglês se impôs a "morte do autor", apesar de que os "telquelianos" se pavoneavam bem vivos por vários continentes, dando conferências e cursos muito bem remunerados e cobrando sem escrúpulos polpudos direitos de autor. Somaram-se a isso, entre nós, as conhecidas brincadeiras que Borges fez sobre a noção de autor ("Borges e eu"), ainda que o criador de Ficciones também não deixasse para o outro Borges virtual nem suas regalias nem seus honorários de celebridade literária.

Essa história da "morte do autor" foi uma fingida desumanização da literatura, baseada na suposta base científica do primeiro estruturalismo que, 
com Saussure como suporte, armava complicados esquemas linguísticos que pretendia transferir para a análise da literatura. Barthes foi o primeiro culpado, mas também o primeiro a se desfazer de todo esse aparelho pseudocientífico, extremamente tedioso, por certo, o qual não tinha nada a ver com sua elegância intelectual e estilística. Existe algo mais tedioso que a "função autor" que propõe Foucault? Poderíamos reduzir Severo a ela? Claro que não queremos, mas eu estaria disposto a postular uma "função Severo" que desse conta da síntese do que seus textos representam para a literatura e para nós como críticos, historiadores e escritores. É o que todos aqui, de uma maneira ou outra, estivemos tratando de fazer, admitamos isso ou não. (Em tempo, pode-se rastrear a "funçáo autor", nos romances de Severo, como recurso literário, mas isso é outra coisa).

Sempre fui um interlocutor um pouco cético de Severo, porque me parecia - a princípio, mas isso evoluiu com o tempo - devotado demais ao movimento estruturalista e pós-estruturalista. Em uma de suas primeiras cartas (de 24 de outubro de 1971), me diz que o estruturalismo é como uma doxa, "um saber estabelecido e difuso que não marca um discurso por si só, doxa por sua natureza (...) aplicável a tudo". Meu entorno intelectual contribuía para fomentar minhas dúvidas, pois só vivia Paris por episódios. Em Yale, eu vivia próximo a Harold Bloom, que se tornou meu amigo e ria dos franceses - ele só domina o inglês como língua de cultura. Acusava-me de afrancesado e, com respeito ao estruturalismo e suas sequelas, cantarolava, citando o Groucho Marx de Horse Feathers (Paramount, 1932): "Whatever it is, I’m against it" ("Não importa o que for, eu me oponho"). Para Harold, o impenetrável Lacan era pouco menos que um farsante. Tinha alguma razão, a meu ver. Eu havia bebido em Lévi-Strauss, Barthes e Derrida (até Glas), mas nunca engoli Lacan, que era superado pela literatura, em especial por Joyce e Proust. Com Foucault, aprendi muito, mas eu resistia a reduzir tudo a relaçôes de poder. Acho que, se tivesse conhecido Mimesis, de Erich Auerbach, Foucault poderia haver economizado sua explicação sobre o trânsito da Idade Média ao Renascimento no que se refere ao signo. A teoria de Auerbach é mais abrangente e convincente, sobretudo para quem se dedica à literatura, porque está fundamentada na evolução da retórica e parte de leituras minuciosas de passagens de obras-primas da tradição ocidental (há, por certo, tradução ao espanhol, mas Auerbach não gozou entre nós da mesma fama que Foucault por faltar-lhe a aura parisiense). Essas diferenças, e outras, faziam de nossas conversas e de nossa correspondência diálogos que revelam o que Severo pensava sobre esses temas e o momento em que opinou sobre eles. 
Outro motivo de meu ceticismo, e pode parecer puro alarde de minha parte, mas é simplesmente um modo de dar conta da condição dos dialogantes, é que eu sabia muito mais que Severo, exceto de literatura e teoria estritamente contemporâneas e de história da arte e pintura. Eu tinha estudado na universidade, em francês, toda a literatura francesa desde os juramentos de Estrasburgo, no século IX (842 A.D.), até Sartre e Camus; é certo que grande parte em antologias, mas também em cursos especializados sobre teatro clássico; a poesia do século XIX e Proust, a quem devorei de cabo a rabo. Severo, por sua vez, me confessava que François lia para ele de noite passagens de Racine. Esse era seu contato com os clássicos. Ele falava francês com a desenvoltura de quem vive em Paris, mas o aprendeu depois dos vinte anos, por isso sempre teve a pronúncia muito marcada pelo sotaque cubano. Chegou a escrever algumas coisas em francês, mas muito poucas. $\mathrm{O}$ inglês que sabia havia aprendido vendo filmes norte-americanos em Cuba, $\mathrm{e}$ depois algo na Índia, por isso soava nessa língua um pouco como um indiano quando, rindo de si mesmo, se atrevia a falar na minha frente.

Severo se dava conta dessa diferença entre nós. Eu era o universitário com formação em literaturas românicas que ele não fora - recordem que ele estudou medicina em Cuba e, depois, história da arte, em Paris. Eu estudei latim e história da língua espanhola, lexicologia e sintaxe - Menéndez Pidal, Lapesa, Gil e Gaya - por isso, Severo, sem recato, me passava os manuscritos de seus romances, depois de De donde son los cantantes, para que eu fizesse correçóes, que ele incorporava sem pensar duas vezes. Tudo o que era meu era seu também. ${ }^{2}$ Severo cometia erros em espanhol, alguns desses erros provenientes do meio cubano que, mesmo em suas mais altas esferas, com as exceçōes de sempre (Mañach, Ortiz etc.), não se podia vangloriar do purismo colombiano. (Mas Severo era da província de Camagüey, onde se falava melhor espanhol que em Havana, o que se notava em sua pronúncia.) Quanto ao barroco, em breve contarei o que compartilhávamos e o que aprendi com ele. Severo, embora conhecesse Góngora, não leu nem Gracián, nem Quevedo, nem Calderón. Tampouco havia lido os trabalhos de Maravall, nem os dos ingleses e alemães sobre Góngora e Calderón, ou o instrutivo ensaio de Wellek acerca da história da noção de barroco, que demonstra ser uma alternância sempre previsível de opostos, com o classicismo como antagonista obrigatório.

\footnotetext{
${ }^{2}$ Eu fiz algumas contribuiçốes concretas e secretas a seus romances. Dei a ele a epígrafe de Paradiso que abre Colibrí e o título do capítulo II, "La muerte vestida de verde jade." Estando na Flórida, uma senhora cubana vinda há pouco do exílio e obrigada a ganhar a vida, me respondeu, quando eu the disse que trabalhar devia ser duro: "Ah, meu filho, é a morte vestida de verde jade". Liguei para Severo para dizer a ele que havia encontrado com um personagem dele. Seu entusiasmo foi tal que ao principio queria dar esse título a todo o romance. Haroldo de Campos se enteirou da frase por Severo e a usou para escrever um poema. Também o fiz recordar Isidro, de quem eu sabia por antigos alunos da Escola de Medicina da Universidade de Havana.
} 
Algo disso chegou a ele por nossas conversas e correspondência.

Conhecemo-nos em Nova York, em 1969, graças a sua amizade com Enrique Pupo-Walker, meu professor em Yale, que havia sido condiscípulo de Severo na Faculdade de Medicina da Universidade de Havana - ambos eram, além de médicos, pintores. Severo regressava de Buenos Aires, onde tinha sido jurado do prêmio Primera Plana. Ele tinha 32 anos e eu, 26. Eu fazia o doutorado em línguas românicas em Yale, com tese doutoral sobre La vida es sueño e obras afins de Calderón, valendo-me do estruturalismo do primeiro momento, Lévi-Strauss e Barthes. Severo já publicara nessa ocasiáo dois romances e seu livro de ensaios Escrito sobre un cuerpo estava próximo de sair. E brilhava tanto na Tel Quel como na Mundo nuevo, revista que Emir Rodríguez Monegal dirigia em Paris, e da qual eu era leitor assíduo desde New Haven. Severo estava no auge, como dizemos em Cuba, eu era um doutorando deslumbrado pela nouvelle critique, ainda que um pouco ingênuo e cético, por conta de minha formação filológica.

Nossa amizade foi imediata: unia-nos Cuba, o barroco, o francês, o estruturalismo, o exílio, a Havana dos anos cinquenta, compartilhada e recordada, seu discurso no rádio e na televisão, o espanhol cubano familiar e até vulgar. Essa amizade durou os vinte e quatro anos que lhe restaram de vida; até 1993, quando morreu. Ele tinha 56 e eu 50. Encontramo-nos muito em Paris, e cheguei a conviver com ele e François Wahl em Saint Léonard e Chantilly, onde passei, certa vez, duas semanas deliciosas com minha mulher e meus três filhos. Em Paris, fizemos rádio, duas entrevistas em vídeo (uma em francês que não consegui localizar), fomos ao teatro, nos reunimos com outros escritores e conversamos sem trégua. Também estivemos juntos em L'Esterel, Canadá (1971), no Rencontre Québecoise Internationale des Ecrivains (onde eu era o único crítico), e também em Boulder, Colorado (em outubro de 1992), onde o vi pela última vez (soube depois que, ao regressar a Paris, recebeu a terrível notícia de seu contágio). Eu havia acertado o seu convite para ir a Boulder e também o de François, porque Severo não viajava sozinho. Antes eu havia organizado um congresso sobre o Neobarroco em Yale, no qual Severo seria a estrela e François falaria no Departamento de Francês, mas na última hora ele não veio porque, me jurava soluçando ao telefone, sua pressão arterial havia subido e o médico não o deixava viajar.

Sua primeira carta é do dia 17 de agosto de 1969, e a última, de 21 de outubro de 1992. São mais de cem no total e vinte cartóes postais. A frequência de suas cartas diminuiu, naturalmente, ao final, devido à sua condição física e à de meu filho Carlos, que estava morrendo e faleceu vítima 
de um câncer aos 22 anos de idade, pouco depois de Severo. Também, com a melhora da situaçáo econômica, falávamos por telefone com mais frequência (o insuportável Guillermo Cabrera Infante me disse, em carta que conservo, que eu escrevia mais sobre Severo que sobre ele porque Editions du Seuil pagava as ligaçôes telefônicas). François achou por bem jogar no lixo minhas cartas a Severo, como fez com as cartas de Manuel Puig, porque "ils se dissaient des énormités" ("eles se diziam barbaridades"). A perda das minhas não é de se lamentar, as de Puig, logicamente, muito. François foi um indivíduo amargurado, difícil, e assim figura na ficção de Severo. Nunca aprendeu uma palavra de espanhol, e, típico francês, só sabia sobre literatura e pensamento em sua língua, e lia os filósofos alemães, sobretudo Heidegger, em tradução. A meu ver não entendeu nada do que escreveu Severo, que ele só podia ler no contexto parisiense de seu momento, e em francês.

A vida de um exilado cubano na Paris dos anos sessenta aos noventa não era fácil, em uma França cuja intelectualidade apoiava quase unanimemente o regime de Fidel Castro, do qual Severo havia escapado. Recordemos o apoio que Sartre deu à Revoluçáo. Os escritores latino-americanos que se radicaram na capital francesa, ou passavam por ali, em especial Cortázar, García Márquez, e, no princípio, Fuentes e Vargas Llosa, eram todos fidelistas. Não esqueçamos, Severo também viveu a Paris de 1968. Ele olhava com pena para aqueles jovens franceses que brincavam de revoluçáo, enquanto ele vinha de um país destruído por uma revolução. Mas, cuidado, era preciso sobreviver e até prosperar e brilhar naquele meio, porque regressar a Cuba era impossível na época das Unidades Militares de Ajuda à Produção (os campos de concentração para homossexuais). Severo não praticou uma política anticastrista, em parte por viver no meio que acabo de descrever, mas também porque sua família continuava em Cuba e podia ser vítima de represálias por parte do governo, sobretudo sua irmã Mercedes, psicóloga infantil, que chegou até a ter um programa na televisão.

Severo foi amigo de todos. García Márquez, Gabo para seus amigos, conseguiu que sua família - irmá e pais - fosse visitar Paris por quarenta dias, e até o ajudou a adquirir um automóvel para eles em Havana. Em Paris, ele encontrava com funcionários do regime de passagem pela cidade, como Miguel Barnet e Pablo Armando Fernández, mas também com os exilados como Guillermo Cabrera Infante e Reinaldo Arenas (a quem fez que se publicasse em francês, mas com quem não se dava bem). Foi colaborador, como eu disse, da revista Mundo Nuevo e amigo de Rodríguez Monegal, e quando este e a revista caíram em desgraça política, foi vítima de ataques por parte de comissários como Roberto Fernández Retamar, que dedicou um insulto homofóbico a Severo em seu felizmente esquecido ensaio Calibán. 
Como Severo aprendeu a escrever cartas e o que há de particular e interessante nas que me escreveu? Em Cuba devem existir ainda manuais do século XIX para aprender a fazer cartas, mas eu não me lembro de ter visto nenhum e duvido que existissem no lar dos Sarduy. (Tenho em mente, aqui, o trabalho de Roger Chartier sobre a correspondência no século XIX francês.) É possível que, na escola primária, se fizessem ditados no gênero carta. No ensino médio, sim, se mencionava e comentava o gênero epistolar, especialmente no livro de Manuel Gayol, Teoría de la literatura, que se estudava no segundo ano e, se não me engano, onde havia um capítulo para esse gênero. Suponho que Severo estudou nele, como eu (ele completou o ensino médio em Cuba; eu não completei, faltou-me o último ano), mas acredito que aprendeu a fazer cartas escrevendo para a família quando se mudou para Havana, e com as cartas que eles escreviam (mas se mudaram logo para Havana a fim de estar com ele). Líamos, isso sim, cartas de Martí.

Mas, nas de Severo para mim, como nas cartas familiares, há muita improvisação. São como um espontâneo diálogo escrito, e a questão que surge delas é a da naturalidade e da sinceridade. Seriam estas possíveis na escritura, em qualquer escritura? Creio que é isso o que aspirávamos em nossa correspondência e acaba por ser algo que a define. Não chegamos a teorizar sobre esse tema, mas ele o merece. Além disso, creio que chegou um momento, que ainda náo consigo localizar bem, em que Severo se deu conta de que, ao me escrever, ele escrevia para a posteridade, que, como crítico, historiador e seu bibliógrafo, eu não ia permitir que os textos que me enviava se extraviassem ou não chegassem a ser conhecidos pelo público leitor.

As cartas pessoais implicam segredos, por isso são "pessoais". O que se diz é só para o destinatário a quem se escreve - a não ser que se trate de uma carta aberta ou pública. No caso das cartas de Severo para mim, não havia temor à censura, ao contrário das que escrevia para sua irmã Mercedes, que enviava a Cuba, onde se sabia que as autoridades liam a correspondência. (Ela publicou um volume não faz muito tempo.) Tampouco havia subterfúgios quanto ao universo sexual, que, sim, existiam em sua correspondência com Mercedes e com a família. Não que eles não soubessem de seu homossexualismo, mas, por pudor, não escrevia a eles (sobretudo para ela) com o mesmo desembaraço com que escrevia para mim. Vemos que também com Puig Severo se soltava - talvez mais do que comigo, porque compartilhava com ele o que hoje chamamos de orientação sexual -, mas observemos que também pairava sobre eles a censura de François, um gay mais pudico, à moda antiga, acostumado à dissimulaçáo. Em todo caso, a ideia é que entre nós não havia segredos e isso dá a esses textos um valor especial, ainda que duvidássemos de que a escritura pudesse 
revelar tudo ou chegar a ser inteiramente sincera e prescindir da retórica.

Fica pressuposto que a carta comunica algo verídico, real, comprovável, que ocorreu e que corresponde ao que o escritor pensa e crê. Expressa, além disso, uma vontade, implícita na redação e no próprio envio; colar o selo no envelope e colocá-lo na caixa de correspondência. As cartas manifestam o essencial de uma existência, por isso se publicam as de personalidades de todas as áreas do saber e da política. Mas a carta, uma vez escrita, é uma expressão separada de seu emissor, sujeita a todas as ambiguidades da escritura, a todas as falsidades, enganos e ironias. ( $\mathrm{O}$ melhor exemplo contemporâneo são as cartas de Pedro Salinas, o poeta espanhol, que escrevia para sua amante norte-americana as mesmas cartas que mandava simultaneamente, com ligeiras mudanças, para sua própria mulher.) Pretendem as cartas superar a ausência e a solidão, procuram alcançar a franqueza, baseiam-se em um pacto implícito entre remetente e destinatário para superar a alienação da escritura.

Se considerarmos que as cartas buscam a soltura e a naturalidade, eram estas características pouco comuns em Severo, que fazia da artificialidade e da simulação parte de sua postura perante a vida e a prática artística. Esse é um tema recorrente em sua ensaística e presente em toda sua ficção. Ele publicou, como sabemos, todo um livro sobre este tema, La simulación (1982), uma espécie de manifesto. A simulação neutraliza a identidade, individual e coletiva, ou, digamos, a recoloca em outros termos. Em Boulder, Colorado, pedi a Severo que se portasse naturalmente para tirar uma fotografia, "se é que isso é possível". Gargalhadas e tapinhas foi sua resposta. A liberdade para escrever de maneira natural depende da relação entre os sujeitos da correspondência, logicamente. Entre nós não havia reservas, nos esforçávamos para eliminar distâncias e ausências. Buscávamos a espontaneidade e não reprimíamos as emoçóes. O “cubaneo" é parte de tudo isso; pressupóe um vocabulário, mas também uma atitude própria do choteo $^{3}$ que foi estudado Jorge Mañach como componente essencial da condição de cubano, e que permeia tudo o que Severo escreveu. Brevemente, o choteo consiste em não levar nada a sério e rebaixar tudo aquilo que ganhe ares de seriedade. Ele manifesta-se em piadas, jogos de palavras, perspicácias e atrevimentos no dizer. Não é a desordem sem limites nem método. Severo gostava de uma sábia sentença cubana: "que el relajo sea con orden" ${ }^{4}$. Ninguém pode negar que o choteo seja a marca (valha a palavra) de nossa correspondência.

$\mathrm{O}$ "desconstrucionista" que ainda sou não me permite aceitar sem reparos as ideias de Severo sobre a simulação. Para começar, a simulação

\footnotetext{
${ }^{3}$ Choteo é um termo que poderia ser traduzido como gozação, faz referência à bricadeira, troça, deboche. Optei por não traduzir o termo, uma vez que ele é utilizado pelo autor em relação a uma configuraçăo muito específica do universo cultural cubano, como fica explícito em uma passagem posterior do texto. [N. do T.]

${ }^{4}$ Que a baderna seja feita com ordem. [N. do T.]
} 
supóe uma identidade que se suprime ou dissimula, mas que por isso mesmo existe ainda que seja como fantasma. Brevemente: Severo propóe que a simulação predomina em certos tipos de arte, como o barroco, claro, e algumas formas contemporâneas, especialmente em pintura e no Mimikry-dress-art, na tatuagem e na maquiagem, bem como atividades afins. (A tatuagem, tão mencionada por Severo, converte a pele e o traço sobre ela em escritura sem alienação, parte de nós mesmos, possuidora de uma permanência cujo único limite é a morte e desintegração do corpo.) A simulação é uma prática em que se apaga ou falsifica o modelo, que apenas serve como pretexto para o que segue, que é o simulacro, o fazer-se passar por outra coisa ou por outro. O modelo, a realidade, é uma ficção necessária para projetar contra ele a simulação. Ela se trata de uma atividade que não tem propósito prático algum, que vale por si só. Severo informa que as investigaçôes feitas para saber se os animais que praticam a camullagem o fazem para se defender dos predadores que querem comê-los confirmaram que não há disparidade numérica entre os mimetizados e os não mimetizados nos estômagos de seus perseguidores. Portanto, a simulação é inútil, válida só em si mesma. Esse é um dos vários exemplos tomados do mundo natural nos quais a simulação se mostra supérflua e serve como argumento universal a Severo para afirmar sua teoria.

Sendo assim, conclui-se que a natureza é já uma simulação, quando se trata de que a simulação supere a natureza, que a suplante, e não que se baseie nela. Sobretudo no barroco, nada pode ser natural, tudo é artificial. Esta é uma contradiçáo reveladora na postura de Severo, como se quisesse reivindicar sua própria condição ambivalente a todo custo. Porque penso que a simulaçáo tem em Severo uma origem pessoal que remete tanto ao seu homossexualismo como a sua condição de exilado. É, além disso, uma teoria do ser que tem sua origem mais decisiva em Heidegger. A sexualidade gay de Severo se erige, dissimulando-se, sobre aquela que aparenta ser a condição "natural", ser homem. Só que é uma dissimulação estridente, espetacular. Assim como o travesti não quer passar por mulher, segundo ele mesmo sustenta, mas, sim, ser uma exageração do feminino que o supera - como um suplemento -, o homossexualismo de Severo vai além da conduta convencionalmente gay. Daí derivava, às vezes, a afetação teatral de Severo, que adorava fazer paródias das "locas cubanas", feminoides ao extremo. Em termos mais gerais, toda a vida de Severo como exilado se apoia sobre uma cubanidade que se torna cada vez mais remota e resgatável apenas através da literatura, dos textos, da linguagem. Isto simula seu frágil ser cubano. Por isso, predomina nesses textos o excesso e a hipérbole, às vezes histéricos, como compensação. $\mathrm{O}$ ser, aqui está o embasamento existencialista, é algo criado do nada e sobre o nada, que se inventa a si mesmo. Creio que essa foi a simulação que compartilhamos em nossa correspondência epistolar, correspondência que era simulação no 
sentido mais profundo. Reinventávamo-nos como cubanos. Por isso, não é que conseguíssemos abandonar a retórica, o que nunca é possível, mas elaborávamos uma outra para nos comunicar. E essa era a do choteo, a de simular que não levávamos nada a sério, exceto, obviamente, a nossa amizade.

Para sintetizar, antes de passar aos textos concretos, as cartas de Severo versavam sobre alguns temas obsessivos que exploramos a seguir.

Primeiro, a nostalgia da Cuba dos anos quarenta e cinquenta, que se manifesta nas repetidas alusóes à cultura popular no plano dos meios de comunicação, mas também no quotidiano mais familiar e caseiro. Há mençóes a cantores populares, como Beny Moré, Celia Cruz, comediantes do rádio e da televisão, como Pototo e Filomeno ou Chicharito e Sopeira, ditados populares que estavam na moda naquela época. Isso se converte em uma espécie de idioma secreto cujo sentido e emotividade residem em seu próprio uso, não no significado que as expressôes possam ter em si. Parte do prazer de usá-lo na carta é estabelecer uma cumplicidade que sabemos confidencial porque só um cubano de nossa idade poderia entendê-lo. Ao publicar a correspondência, deverá ser feita uma anotaçáo minuciosa para torná-la inteligível.

Segundo, a obsessão do regresso a Cuba, que Severo vive através de mim, porque eu regressei em 1978 duas vezes como parte do que se chamou o "diálogo", para supostamente negociar a saída de prisioneiros políticos. Os participantes éramos exilados de esquerda, razáo pela qual a direita colérica de Miami nos ameaçou de morte e, de fato, assassinaram a dois de nós. Severo tinha um medo bem fundado por causa da existência dos campos de concentração para homossexuais que mencionei acima. Ele temia que o retivessem em Cuba por haver recebido uma bolsa Guggenheim, por não haver regressado da viagem que o governo cubano lhe pagou para que fosse estudar história da arte em Paris, porque havia estado vinculado a Mundo Nuevo. Tinha terror de entrar em Cuba e náo poder sair outra vez, o mesmo que eu senti em minha primeira viagem, quando ainda estava em idade de serviço militar (tinha trinta e cinco). Mas ele, como todo exilado, reclamava sua terra, sua gente e, especialmente, sua família. $\mathrm{Eu}$, ingenuamente, em minhas descartadas cartas, e pessoalmente, o incentivava a retornar, dizendolhe que o impacto do regresso iria inspirar uma grande obra. Mas ele não o fez, nem sequer quando os comissários o convidaram para um colóquio sobre sua obra em Havana - conservo a infame carta que Roberto Fernández Retamar fez chegar a Severo por meio de Lilia Esteban Hierro, a esposa de Alejo Carpentier. Severo sentiu uma grande satisfação ao ver um adversário seu rebaixar-se dessa maneira, mas em certa medida já era demasiado tarde e os temores, sobretudo o de não poder regressar a Paris, não haviam desaparecido. Ele ficou fascinado com meu regresso e me enchia de perguntas sobre o que 
havia encontrado lá, mas eu não era Severo, nem podia ter os mesmos medos.

Terceiro, o deboche dos burocratas e funcionários encarregados do campo da cultura em Cuba, alguns, como Retamar, que Severo conhecia em pessoa, outros, como Cintio Vitier e Fina García Marruz, sua esposa, vestígios do grupo Orígenes, que se faziam passar por tolerantes e generosos, e com quem se encontrou em um colóquio em Caracas, mas que estavam devotadamente entregues ao regime. Severo não era mencionado em Cuba, embora se aludisse a ele em termos depreciativos de maneira indireta, sem mencionar seu nome. Lembro que, quando saiu o primeiro volume do Diccionario de la literatura cubana (Severo o chamava "História local do descaramento"), que não chegava à letra "s", fazíamos apostas se iam ou não incluí-lo no segundo volume. Não apareceu Severo, e eu nem sequer apareço na bibliografia da entrada "Alejo Carpentier", apesar de minhas numerosas publicaçôes sobre o autor de El siglo de las luces, a quem levei à Universidade de Yale um ano antes de sua morte.

Quarto, a evocação e o louvor a Lezama, a quem Severo realmente descobriu depois de chegar a Paris. Quando Paradiso apareceu, ele já estava na França. Severo náo chegou a publicar em Orígenes, mas sim na revista rival e dissidente chamada Ciclón, dirigida por José Rodríguez Feo, que se tornou inimigo do autor de Paradiso em uma das mais destacadas brigas da história da literatura cubana. Com Lezama, ele teve alguma correspondência (ver a carta comentada no Cristo da Rue Jacob), e seu reconhecimento do valor da obra lezamiana foi fundamental para Severo. Severo publicou Paradiso em Editions du Seuil, em traduçáo que promoveu e supervisionou (ainda assim é um romance demasiadamente cartesiano em francês, o que talvez fosse inevitável). Em Lezama, Severo encontrou uma obra literária que era como o contrapeso de tudo o que se estava fazendo à sua volta em Paris. Deu-se conta de que o extravagante, original, desdenhoso de toda moda e monumental romance Paradiso era mais importante que Lacan, Derrida, Foucault e todos os outros. Penso que isso o fez mudar de rumo depois de Cobra. Contra toda a artificialidade parisiense, erguia-se a densa, descuidada, pré-adâmica e profunda prosa de Lezama. Severo me dizia que sua própria obra ia ser, no melhor dos casos, uma nota de pé de página à obra de Lezama. Quando Vitier fez a edição de Paradiso para a Coleção Archivos, que é uma vergonha para a crítica cubana e latino-americana por sua radical falta de rigor filológico, teve por bem convidar Severo para colaborar com um ensaio. Severo o tomou como um de seus mais importantes trabalhos de crítica, que quis intitular "El heredero", mas Vitier alterou para "Un heredero".

Quinto, os muitos comentários, invariavelmente críticos, sobre Carpentier, mas não por motivos políticos (Carpentier tinha um posto diplomático - menor por certo - na delegação cubana em Paris), e sim pela 
postura deste perante o barroco. ${ }^{5}$ Havia coincidências entre os dois - longos períodos na França, rádio e jornalismo em Paris, interesse pela pintura e pelo barroco, barroquismo estilístico - mas também diferenças fundamentais. $\mathrm{O}$ estrato social, indiscutivelmente. Carpentier havia tido uma infância e primeira juventude privilegiadas em Havana, onde frequentou os melhores colégios privados, foi criado falando francês em sua casa e fez longas viagens pela Europa com sua família. Seu pai havia sido um arquiteto francês importante, mas que um dia desapareceu, deixando o adolescente Alejo aos cuidados de sua mãe e sem meios de subsistência. Severo era um mulato da classe proletária e do interior; seu pai havia sido empregado ferroviário. Carpentier era um indivíduo elegante, com presença de grande senhor. Falava francês como um nativo, amante de várias mulheres e casado três vezes, enquanto Severo se deixou arrastar pelo meio homossexual havanês de Rodríguez Feo e logo fez uma vida gay em Paris, sem maiores disfarces, como já era possível em sua época.

Severo acusava Alejo de ser seguidor de Eugenio d'Ors em sua aproximação ao barroco. Essencialmente, crente que o barroco imitava a natureza proliferante, numa concepçâo romântica. Essa era uma ideia infundada e eu insistia com Severo, sem convencê-lo. Ademais, em La simulación, ele mesmo apela à natureza como modelo, como já vimos. Eu, francamente, creio que Severo havia lido muito pouco da obra literária de Carpentier, que tem, por certo, muito mais em comum com a sua própria e até com a de Lezama do que ele acreditava ou aceitava. Eu conheço detalhadamente a obra de Carpentier, que admiro sem reservas, exceto por seu último romance, La consagración de la primavera, que foi um fracasso. Penso que o rechaço de Severo era atávico e de origem edípica. Foi um debate que nunca pudemos resolver.

Sexto, muito sobre os escritores do boom, que Severo, em alguma carta, chama o "bluff". Escreveu páginas agudas sobre o priapismo dos Buendía, e teve, como já mencionei, uma amável relaçáo com Gabo, apesar das discrepâncias políticas. Parece que também se dava bastante bem com Fuentes, que incluiu personagens de Severo em seu exorbitante Terra Nostra. Mario Vargas Llosa nunca aceitou Severo. É ele o escritor referido no prólogo de meu livro La ruta de Severo Sarduy, que me perguntou: "todo um livro?", quando eu lhe disse que escrevia uma obra sobre Severo. Cortázar, que nunca colaborou em Mundo Nuevo e foi fiel ao aparato cultural cubano, nunca teve nada a ver com Severo. Como sugeri várias vezes, toda a literatura de Severo pode ser vista como escrita em contraste com a do boom, que, apesar de seu aparente experimentalismo, essa produção continuava atada a um

\footnotetext{
${ }^{5}$ Foi conselheiro cultural, nunca embaixador, como foram Neruda, Paz e Fuentes, nem sequer adido cultural.
} 
pacto mimético-realista, que Severo havia rechaçado por completo, e a uma concepção de totalidade, impossível de encontrar no autor de De donde son los cantantes. Visto em contraste com Cobra, um romance como Rayuela é praticamente galdosiano.

Sétimo, às vezes menciona brevemente Octavio Paz, sempre com afeto, mas com um ligeiro toque de ceticismo. Consta-me que Severo achava ingênua a atitude de Paz perante a Índia, parecia-lhe colonialista, marcada pelos lugares-comuns dos intelectuais europeus sobre ela ao longo dos anos. Severo pensava que a única Índia à qual tínhamos acesso e podíamos representar era a irrelevante, mercantil, superficial e turística, promovida pelos próprios indianos, não a supostamente profunda, distante e inacessível da tradição ilustrada que Paz manejava (parece que Octavio passou toda sua temporada na Índia trancado na embaixada, provavelmente lendo sobre a Índia). Essa Índia de quinquilharia é a que aparece nos romances de Severo; é para ele a única Índia "verdadeira" para um ocidental. Severo nunca escreveu abertamente sobre isso porque sentia uma genuína amizade pelo grande poeta mexicano e, além disso, em suas revistas Plural V Vuelta, Paz abria para Severo o mundo latino-americano ao qual náo tinha acesso porque carecia de um país próprio que disseminasse seus escritos, como fazia o regime com os autores cubanos em Cuba. Paz, além disso, foi marcadamente anticastrista, e desde muito cedo.

Oitavo, muitos comentários sobre suas viagens ao Oriente Médio e à Índia, e não poucos cartões postais desses lugares. Para Severo, lugares como Marrocos eram também, além de fascinantes por conta de seu interesse por tudo que fosse oriental, representaçóes de Cuba. Os postais que me enviava o comprovam. Em um deles, há uma estrada flanqueada por palmeiras reais, duas grandes colunas paralelas, que me lembra a entrada de uma usina açucareira na província de Las Villas, em Cuba. Em outra, há ídolos, sobretudo uma virgem, que se parecem muito às virgens cubanas, a da Caridade do Cobre e a de Regla. Em La ruta de Severo Sarduy, estudei essa transposição que é tanto literária como íntima.

Nono, Severo sempre apresentava em suas cartas comentários generosos sobre meus trabalhos dedicados à sua obra e ao barroco, a Calderón especialmente, onde o diálogo entre nós foi frutífero para ambos, em particular para mim. Mas vou deixar isso para mais adiante, quando analisar uma carta dele sobre esses temas.

5

Começo por esta carta de 16 de maio de 1972, em que afloram assuntos sobre nossa relação que são pertinentes para entender a correspondência entre mim e Severo. Não vou incluir "sic" para indicar faltas de ortografia, sintaxe, 
léxico e outros defeitos. Acredito que estes fazem parte da comodidade com que Severo me escrevia, conforme falei antes.

Querido Roberto,

París, mayo 16-72

Pongo la máquina a dos espacios y te escribo a vuelta de correos a tal punto me conmueve tu carta en papel de bodega con olor a galletas la Paloma de Castilla. Creo que nuestra correspondencia y el paralelismo de nuestras preocupaciones llega a un grado casi esotérico - y es una lástima, sea dicho de paso, que no vivamos juntos. !en la misma ciudad quiero decir majo! -: yo también me torturo a cada día pensando que como pensamos no podemos vivir donde vivimos, que nuestro silencio y nuestra vida sirve de caución - no sé como se dice eso - a una serie de eventos grotescos, que afortunadamente que el alcohol y los papayones o lo que sea pueden hacernos olvidar la contradicción enorme en que vivimos; como sabes pertenezco por asi decirlo a Tel Quel "grupo de maos", y sin pertenecer a Tel Quel basta con leer la prensa; estamos en convulsión politica y moral y yo no quiero hablar de los ángeles mientras caen las bombas... enfin, me estoy dejando ir, la olivetti escribe sola, esa retórica es también grosera.

Creo que Cobra - que por cierto sigue viento en popa - escapa un poco la frivolidad y protesta a su manera al reivindicar una ideología sexual transgresiva, al minar el lenguaje, etc, pero vivo como una pregunta concreta y cotidiana y una participación más activa a lo que ocurre y no veo por dónde empezar, esa es la pregunta de los 36 mil dólares; estamos tu y yo en tres y dos.

Ahora bien, todo trauma tiene una solución catastrófica: la nuesta - la tuya-sería de tipo regresivo, con las tres connotaciones más a mano de la palabra: regreso a la isla-claustro materno, etc., regreso físico e intelectual y conducta de tipo reaccionario, en cierto modo. No es la pequeña agitación revisionista, catolizante, moral y pequeño burguesa, el reino de los arrivistas y los mediocres instalado en Cuba lo que puede responder a la inquietud radical, coño, que padecemos. Se trata de cambiarlo todo, desde el modo de pensar hasta el modo de mamar, y esto no es una boutade. Todo: y esto no va a pasar hasta que algo no estalle adentro, - otra vez el lirismo metafísico! -. No sé. Tenemos que hablar.

Oye, trata de que me manden esa revista pues quiero verme-nos. No podemos juntarnos, tu y yo, en uno, porque eso es una actitud reaccionaria; pero podemos, eso si, dividirnos cada uno en dos.

Un abrazo,

Severo

Também na dedicatória para mim em La simulación, refiro-me à escrita a mão sobre a página anterior à titular, diz: "A Severo, de su Roberto, COLECCIÓN ESTUDIOS, en Saint Léonard, 20 de Mayo, 1982”. Ou 
seja, Severo converte cada um no outro. A propósito, o número vinte aparece sublinhado e maio com maiúsculas porque essa costumava ser a data em que se celebrava a independência de Cuba. É um código secreto, ou só para cubanos.

A seguir comento a carta. Nas primeiras linhas se lê: "tu carta en papel de bodega con olor a galletas la Paloma de Castilla". A bodega, loja de víveres, em muitos casos pertencentes a espanhóis, era parte essencial da vida quotidiana em Cuba porque os "mandados", como se chamavam os víveres, eram comprados diariamente, sobretudo em províncias, pela falta de refrigeração. Era, além disso, um centro de convergência de donas de casa, criadas, cozinheiras e homens que, às vezes, tomavam um gole ali, conversavam e cantavam as mulheres. $\mathrm{O}$ papel pardo que se usava para as listas de comestíveis e os "cartuchos" ou bolsas de papel eram rústicos e vulgares, de cor marrom claro. Usá-lo para escrever era sinal de certa falta de classe (Severo era fascinado por todas as escrituras). Os biscoitos eram parte importante da dieta cubana porque se conservavam bem, e penso que, por isso, se levavam nas embarcaçóes que faziam viagens longas. Eram habituais nas casas cubanas, e se comiam com doce de goiaba nas merendas. A marca "Paloma de Castilla" deve haver existido, mas eu não me lembro. Em todo caso, alude ao consumo predominantemente espanhol das bodegas.

"y es una lástima, sea dicho de paso, que no vivamos juntos! en la misma ciudad quiero decir majo!". No início de nossa amizade, Severo coqueteava comigo, mas logo se deu conta de que eu era insensível ao erotismo gay, e entáo se dedicou a tratar de procurar mulheres para mim, para me observar em ação (não literalmente). Severo gostava de seduzir homens, não gays, porque com esses lhe parecia redundante. Isso é típico dos homossexuais cubanos e é algo que os homens aproveitavam sem se considerarem a si mesmos homossexuais. O uso de "majo" se dá porque em Cuba debochamos cruelmente dos espanhóis, os "gallegos", como os chamamos, por um preconceito de classe, porque a imensa maioria deles eram imigrantes pobres, de áreas rurais da Península Ibérica, sem maior educação. Falavam mal o espanhol porque em muitos casos esse não era seu idioma nativo. Eram algo assim como os "tanos"6 para vocês, suponho.

"que afortunadamente que el alcohol y los papayones o lo que sea pueden hacernos olvidar la contradicción enorme en que vivimos...". Severo chegou a beber bastante, sem dúvida para mitigar as angústias do exílio, como diz aqui. Ele gostava de vodca com suco de tomate, Bloody Marys. Nunca o

\footnotetext{
${ }^{6}$ Considerar que a conferência foi proferida em Buenos Aires. Em espanhol rio-platense se chama coloquialmente de "tano" os habitantes ou naturais da Itália, assim como os descendentes de italianos. O termo vem da aférese fonética de 'napolitano' (originário de Nápoles), pois uma grande quantidade de italianos que chegaram ao Rio da Plata entre o fim do século XIX e princípios do XX eram emigrados dessa regiáo italiana. [N. do T.]
} 
vi bêbado, mas, sim, meio alto. Escreve sobre isso com riqueza de detalhes no Cristo de la rue Jacob. Papaya é, obviamente, a fruta, mas na maior parte de Cuba - não toda - a palavra só quer dizer "órgão sexual feminino". Severo me oferece essa alternativa, atento a minhas inclinaçóes, enquanto se reserva para ele "lo que sea", em outras palavras, o órgão masculino.

"como sabes pertenezco por así decirlo a Tel Quel 'grupo de maos', y sin pertenecer a Tel Quel basta con leer la prensa; estamos en convulsión política y moral y yo no quiero hablar de los ángeles mientras caen las bombas...”. Nessa época, princípio dos anos setenta, o grupo Tel Quel fez uma inflexão maoísta. Severo me disse que o deixaram subir ao aviáo para uma viagem para a China por ser de origem cubana, ainda que cidadáo francês. Acho que é uma melodramatização do acontecimento, não um relato verídico. Não entendo a alusão aos "ángeles mientras caen las bombas". A situação política do grupo tornava a vida de Severo difícil.

"pero vivo como una pregunta concreta y cotidiana y una participación más activa a lo que ocurre y no veo por dónde empezar, esa es la pregunta de los 36 mil dólares; estamos tu y yo en tres y dos". Vemos aqui o dilema de Severo. Ele se equivoca, era a pergunta dos 64 mil dólares, tomado do programa de televisão americano com esse nome, em que os participantes podiam ganhar essa quantia se davam a resposta correta a uma pergunta. "Estar en tres y dos" é uma expressão do baseball que se usa quando o batedor está em uma situação difícil, com o limite de bolas e strikes, por isso, ele tem que decidir se atira ou não a próxima bola. Severo não sabia quase nada de baseball, mas essa expressão é muito comum no espanhol cubano, até entre os que não conhecem sua origem.

"sería de tipo regresivo, con las tres connotaciones más a mano de la palabra: regreso a la isla-claustro materno, etc, regreso físico e intelectual y conducta de tipo reaccionario, en cierto modo. No es la pequeña agitación revisionista, catolizante, moral y pequeño burguesa, el reino de los arrivistas y los mediocres instalado en Cuba lo que puede responder a la inquietud radical." Aqui temos a obsessão com o regresso a Cuba, que Severo compara com o regresso ao útero materno, e que atribui a mim porque ele intuía que eu ia regressar... Náo sei o que quer dizer com "conduta de tipo reacionário", salvo que adscrever-se ao regime supóe semelhante conduta. A "agitação revisionista, catolizante, moral e pequeno burguesa” parecem-me uma alusão clara ao casal Vitier-García Marruz, a quem, sem dúvida, se pode aplicar esses adjetivos.

"Oye, trata de que me manden esa revista pues quiero verme-nos. No podemos juntarnos, tu y yo, en $\underline{\text { uno}}$, porque eso es una actitud reaccionaria; pero podemos, eso sí, dividirnos cada uno en dos." Refere-se a uma revista venezuelana em que apareceu uma entrevista que fiz com Severo, mas o de 
juntar-nos e dividir-nos cada um em dois me lembra De donde son los cantantes. Às vezes, quando Severo queria influenciar no que eu escrevia sobre ele, eu o advertia que tínhamos que ser diferentes, como Auxilio e Socorro. Queria me absorver em seu mundo fictício.

Estou seguro de que Severo não tinha ouvido falar de Calderón desde a escola. Em Cuba líamos, quando muito, fragmentos dos famosos monólogos de Segismundo. Por isso, talvez, o fascinou desde o início de nossa amizade meu interesse pelo dramaturgo madrilenho. Estava encantado com alguns títulos de Calderón que eu mencionava, como Fieras afemina amor e La aurora en Copacabana, assim como com os argumentos de El monstruo de los jardines e de La hija del aire. No primeiro, Aquiles aparece disfarçado de mulher, e, no segundo, Semíramis, rainha da Babilônia e seu filho Ninias, que são idênticos, se disfarçam, um se fazendo passar pelo outro. Eram essas comédias que eu estudava em minha tese de doutorado. Por causa de Severo e sua ênfase na figura do travesti, consegui entender como funcionavam esses personagens em Calderón, e propus a figura do monstro como emblemática do barroco. Pude ver que era feito de características opostas complementárias e correlativas, homem-mulher, humano-besta, que funcionavam de maneira sistemática, armando assim um relato por debaixo ou por cima do argumento das comédias. A isso se somava a natureza visual da figura. Monstro, de "monstrare", algo digno de ser visto, maravilhoso por seu aspecto físico inusitado, como os personagens de Severo, e o vínculo do monstro com a reprodução anômala, antinatural. Para Covarrubias, "MONSTRO é qualquer parto contra a regra e ordem natural, como nascer o homem com duas cabeças, quatro braços e quatro pernas...". Em La vida es sueño, primeiro Rosaura aparece vestida de homem, e Segismundo, de fera. Os dois mudam de disfarce ao longo da comédia, mas terminam com disfarces mistos compostos de ambas as naturezas. A sexualidade em Calderón surge não como algo natural, mas como essencialmente artificial, uma combinatória de oposiçóes binárias que armam um aparato complicado, sistemático, preciso, sólido e efêmero ao mesmo tempo, e, por isso, barroco. Tudo isso pude ver graças a Severo. O que eu não soube explorar foi o erotismo nessas figuras contraditórias em Calderón, que passeiam como drag pelo cenário. Isso fica pendente para escandalizar outra vez os críticos calderonianos.

Mas Severo viu em seguida que, como Segismundo náo mata seu pai, o rei Basílio, ao coroar-se monarca, La vida es sueño tem dois centros, o que o leva a suas teorias sobre a elipse. Brilhante e sugestivo. Mas está aludindo, na carta que reproduzo em seguida, a outro elemento calderoniano, que 
eu aproveito em meu ensaio "Memoria de apariencias y ensayo de Cobra", que é a publicação minha que ele e François comentam. As "memorias de apariencias" são uns textos maravilhosos, mas pouco conhecidos de Calderón. Consistem nas instruçóes que o dramaturgo escreveu para os tramoyistas ${ }^{7}$ sobre como fabricar os cenários dos autos sagrados, que se representavam sobre carros nas praças dos povoados, e que eram complicadas alegorias em que se podia representar o universo terrestre e o sideral, e onde apareciam personagens como o Demônio, o Homem, a Graça etc. "Memoria” queria dizer simplesmente lista ou relaçáo de indicaçóes precisas para os cenógrafos, mas eu tomei a palavra em um sentido mais platônico como "recuerdos de simulacros", o que acabou por me conduzir ao texto de Severo e à sua própria natureza efêmera, falaz e, portanto, barroca. O jogo de minha parte está no fato de que as aparências às quais se refere Calderón são muito sólidas e tangíveis - feitas de madeira, gesso e pintura, entre outros materiais, suponho -, enquanto as que eu conduzo são abstraçóes alegóricas, pura linguagem poética. Entre as duas surge, a meu ver, o mundo de Severo e é o que tem em comum com o barroco calderoniano. Em todo caso, segue aqui a carta:

Saint Léonard, 17-III-74

Querido Roberto: si me pusiera un sombrero en forma de caja de camambert, si me pusiera una piel, sintética, de zorro, si lo guardara todo en una cartera comando, enfin, si me disfrazara hoy de concerje megalómana, por mi cabeza pasaria una sola idea: Calderón hizo con la iconografia cristiana lo que yo hago con la búdica, es decir, des-construcción y re-composición fantasmática. Los elementos de ambas "morales", o sus simbolos, se pulverizan para reconstituirse en una combinatoria que les hace decir otra cosa, al mismo tiempo -árboles de jardin y árboles de genealogía-, siempre en Don Pedro, acorde con el cristianismo, signos plenos, desbordantes, pues conduce a un saber suplementario-botánica y herencia-; en la megalómana de la cereza en el sombrero, signos que, acordes con el budismo, están recompuestos para conducir a un saber "deceptivo", para llevar al que los recibe a la noción de vacuidad. Hay un árbol con las hojas escritas en Cobra, si mal no recuerdo, pero el saber que conducen es o nulo o irrisorio, pronto vemos los mismos signos sobre un glande, creo, cito de memoria. La diferencia es que estos divinos blasones y carros de 1661 son apariencias no en el sentido más fenomenológico, pues la parusía o epifanía soporta un emisor central, real o pleno, la fé, Cristo, el Símbolo, etc; los carros carnavalescos del Prado, son puro trompe-l'oeil, señalan, en lo manifiestamente barato y ligero de sus materiales, que no sustenta ninguna fe, el mecanismo de la apariencia como único fin. Pero ya, porque sobre este texto [el mío] tan delirante y genial, sobre todo la astronomía

\footnotetext{
${ }^{7}$ Profissional responsável pela operação dos sistemas mecânicos teatrais, responsáveis por efeitos como voos, incêndios e explosōes cênicas, especialmente populares no teatro barroco. [N. do T.]
} 
al final, podriamos hablar horas. Recuerda también un "triunfo de Piero de la Francesca que está en Florencia. Gracias por el placer del texto. Respondo ahora a tu carta párrafo por párrafo.

Estoy loco por escribir. Me voy a Oriente, no sé a donde, a Irán quizás, a escribir la segunda parte de un novelón, Maitreya. Dejo caer, pues, Indiana y Yale. Estoy cansado. Necesito sol. François se va a China con Roland y Philippe.

Diacritics. Propongo el desarrollo de Barroco sobre la elipse y la elipsis. Se habla mucho de Lezama, puede servir, qué te parece?(Al tercer párrafo, un acierto tuyo literario que me impresionó tanto que me dió un sofoco interno (noción con que trabajo ahora y que debo a un brasilero borracho): "aburrimiento minucioso". Iré al Hilton de Teherán, todos los hiltons son iguales; daiquiré y mulatas, o su equivalente o erzat, moritos jacarandosos.

Por correo aparte va Big bang, metáforas astronómicas tomadas al pie de la letra y el adjetivo Verde con mayúscula: el nombre de un portugués recomendado por Alejandro. Es la edición banal, para no enviar la de lujo que cuesta un cojón.

La segunda parte de Cobra no halló gracia ente los ojos del editor americano. tant pis.

De Ramón, tuvo la gloria de un texto enorme de Tony Duvert, el premio Medicis de este año. Por mi parte, yo entré en el jurado Medicis internacional, con Roland, Robbe-Grillet, Butor, etc. Qué será de nosotros?

Yo también quiero tomarme contigo un wodka con jugo de tomate en el Flora. Saludos a Isabel. Jeff será recibido con los brazos abiertos.

Leo a François el Calderón y mi carta. Añade que:

"Lo importante es que en un caso es una apariencia que es apariencia de algo que se puede conocer y que conduce a eso y en el otro caso, en el mío, apariencia sin reverso. François dice además que prefiere eliminar la alusión a la fenomenología porque implica algo tan diferente en Husserl o en Heidegger que mejor es evitarla.

Yya, escribe contando en detalle, por favor, los dos encuentros. Yo saldré a Irán el 5 de Abrily volveré hacia el 22. Fuego a la lata, hasta que suelte el fondo!

Steady Statel

Severo Sarduy

Aqui meus comentários:

"si me pusiera un sombrero en forma de caja de camambert, si me pusiera una piel, sintética, de zorro, si lo guardara todo en una cartera comando, enfin, si me disfrazara hoy de concerje megalómana”. O disfarce que se propóe Severo é parecido ao de alguns de seus personagens, sobretudo em Maitreya e Cobra. É extremamente ridículo, como o que se vestiria um travesti para circular pela rua e chamar a atenção. Severo se "veste" assim para atenuar a vaidade extrema, a vaidade de se comparar a Calderón. Severo usava o ridículo 
sem cuidado, estava disposto a assumi-lo, não com a afetação afeminada das "locas cubanas", mas sim com o trabalho dos personagens parisienses que ele conhecia bem (eu conheci alguns). Nunca o vi disfarçado, nem tinha, que eu saiba, nenhuma tatuagem; tudo ficava no plano da escritura. Eu o instava, com meu perfil universitário, a se dedicar aos verdadeiros clássicos do idioma, não aos seus efêmeros contemporâneos, nem sequer a Octavio Paz.

"Calderón hizo con la iconografía cristiana lo que yo hago con la búdica, es decir, des-construcción y re-composición fantasmática. Los elementos de ambas 'morales', o sus símbolos, se pulverizan para reconstituirse en una combinatoria que les hace decir otra cosa, al mismo tiempo -árboles de jardín y árboles de genealogía-, siempre en Don Pedro, acorde con el cristianismo, signos plenos, desbordantes, pues conduce a un saber suplementario-botánica y herencia-; en la megalómana de la cereza en el sombrero, signos que, acordes con el budismo, están recompuestos para conducir a un saber 'deceptivo', para llevar al que los recibe a la noción de vacuidad.” Severo confessa aqui uma tendência alegórica em sua escritura que eu analisei em outras ocasióes. Em Calderón, o sistema doutrinário de referências é o cristão, está claro, mas sua armação alegórica se vale de outros saberes - botânica e herança -, como é usual. Severo poderia ter acrescentado a astronomia. A relação entre esses saberes e a mensagem doutrinária é plena, abundante, o que se reflete na exagerada cenografia, rústica e grosseira por natureza, dirigida a um público, em sua maior parte, analfabeto, mas crente. Severo, pelo contrário, efetua um processo similar, mas a iconografia conduz não à fé na solidez da doutrina, mas sim ao vazio. A isso alude François em seu post-scriptum, ao que se soma o desacerto, diz ele, de invocar a fenomenologia, porque em Severo não haveria fenômenos, como as "aparências" de Calderón. Tudo sempre remete a um vazio, a uma ausência do sujeito, que sempre me parece heideggeriana, existencialista, disfarçada de budismo, neste caso. Nunca me convenceu o budismo de Severo, como tampouco sua crença na santería, ambos eram astúcias dele: Severo não acreditava em nada, como fica claro em Pájaros de la playa, escrito à beira da morte. O que tem sentido: todo o seu arsenal barroco era uma invenção sem fundamento nenhum, sem fé que a sustente. Por isso, o saber é "deceptivo", como diz com um galicismo baseado em um barbarismo, porque a palavra náo existe em francês, segundo meu Robert. O que está por trás de sua ideia, mas que ele não sabe, é o conceito de "desengano" que, sim, é inicialmente barroco, calderoniano, quevediano e gracianesco.

"La diferencia es que estos divinos blasones y carros de 1661 son apariencias no en el sentido más fenomenológico, pues la parusía o epifanía soporta un emisor central, real o pleno, la fe, Cristo, el Símbolo, etc; los carros carnavalescos del Prado, son puro trompe-l'oeil, señalan, en lo manifiestamente 
barato y ligero de sus materiales, que no sustenta ninguna fe, el mecanismo de la apariencia como único fin." Severo entendeu o que eu pretendo ver nessas memórias de aparências de Calderón: que elas também, por sua própria e exagerada materialidade, são puros "trampantojos" (ele não conhece essa palavra e usa a francesa trompe-l'oeil), isto é, em última instância, elas não significam mais que sua própria aparência. Isso não era concebido assim pelo dramaturgo, mas está, de forma explícita, a meu ver, em suas descriçôes de como se armam literal e materialmente as alegorias. Mas é necessário vê-lo com a distância de meu próprio descrédito e esteticismo, que me permitiram oferecer um Calderón distinto ao da crítica tradicional, em especial a espanhola, que o reduziu à beatitude católica.

"Recuerda también un 'triunfo' de Piero de la Francesca que está en Florencia. Gracias por el placer del texto.” A evocação do triunfo de Piero della Francesca (a ortografia de Severo era desigual, como poderão ver) é reveladora, porque mostra como sua mentalidade de historiador da arte fazia associaçóes nesse plano, e como estas sáo coerentes com seu pensamento. No triunfo aludido, aparece um carro de cavalos, com toda uma cena na parte superior, o qual remete às aparências de Calderón. Porém, o mais interessante é que Piero foi dos primeiros pintores, contemporâneos de Alberti, que deram importância à perspectiva e tinha um conceito geométrico da realidade que representava. Trata-se de um momento decisivo na história da arte, como sabemos. Mas a afinidade de Severo com della Francesca reside no matemático e no geométrico de seu conceito da mimesis, que, sem dúvida, antecipa a sua, ou na qual vê algo familiar e estimulante.

"De Ramón, tuvo la gloria de un texto enorme de Tony Duvert...". Ramón é o pintor cubano Ramón Díaz Alejandro, o Alejandro de algumas linhas acima, com quem Severo colaborou no livro que menciona, Big Bang. Houve outras colaboraçóes entre ambos, mas sua amizade com "La Mongui", como ele o chamava (de Mongo, por Ramón), foi tempestuosa e esporádica. Lamentavelmente, Alejandro decidiu se vingar falando mal de Severo em suas memórias. Foi muito meu amigo e irmão de um querido colega de Yale, da área de economia, autor de estudos importantes sobre a Argentina. Big Bang permitiu a Severo expressar suas teorias cosmológicas com acompanhamento pictórico de alta qualidade.

"Steady State." Severo gostava de brincar com suas iniciais, esses "esses" repetidos, que eu poderia dizer "fezes", como brincadeira. Em todo caso, na cosmologia, o Steady State, estado estável, é uma teoria alternativa à do Big Bang, da evolução do universo. Nessa teoria, a densidade da matéria

\footnotetext{
${ }^{8}$ Trampantojo é o nome utilizado para denominar a técnica pictórica que tenta enganar a visão jogando com o entorno arquitetônico, com a perspectiva, o sombreado e outros efeitos ópticos. [ $\mathrm{N}$ de T.]

9 "heces" no original, palavra que em espanhol tem pronúncia idêntica a "eses".
} 
no universo em expansão permanece imutável dada a constante criação da matéria, pela qual o universo observável continua igual em qualquer momento e lugar. Foi superada pelas provas em favor da teoria do Big Bang. Mas Severo gostava da ideia de que ele, apesar dos avatares de sua vida, seguia uma rota constante e firme.

"Fuego a la lata hasta que suelte el fondo." É um ditado vulgar cubano que quer dizer fazer algo com a maior intensidade possível, colocar fogo em uma vasilha até que se calcine sua base.

As duas cartas que comentei são relativamente antigas. No final, que Severo não previu que fosse tão rápido, quando descobriu que estava doente, houve mudanças provocadas, primeiro, pela maturidade, e, depois, pela antecipação da morte.

Já para o final dos anos oitenta, o tom de Severo mudou, com uma inflexão muito mais abertamente autobiográfica, algo que ocorre a não poucos escritores à medida que amadurecem (Cervantes, por exemplo), como se reparassem que, apesar de sermos um mistério insondável, está em nós mesmos o que mais promete nos aproximar de uma verdade - ainda que isso seja falacioso, como sabemos desde Freud, inclusive, desde muito antes, pela literatura mesma e por pensadores como Santo Agostinho e Rousseau. Essa tendência de refletir sobre sua vida, nota-se em livros de ensaios como $\mathrm{La}$ simulación e El Cristo de la rue Jacob (esta rua, em Saint-Germain-des-Prés, é onde ficava a Editions du Seuil, com os escritórios de François e Severo). É, claramente, também uma virada em direção às coisas cubanas e até provincianas de sua origem. Nota-se, sobretudo, em um romance como Cocuyo, no qual aparecem objetos tipicamente camagüeyanos, como os tinajones ${ }^{10}$. Mas, aflora de maneira muito especial em seu cultivo da décima, o verso cubano, rural, por excelência, e, ao mesmo tempo, uma das estrofes mais exigentes da versificação castelhana, praticada pelos poetas barrocos, como Calderón, que incluiu algumas décimas memoráveis em La vida es sueño. No campo cubano, os decimistas improvisam e entabulam pelejas em que se desafiam com afetação teatral, cantando seus poemas com vozes um pouco fanhosas, sempre afetadas e retóricas. Na modernidade, há poucos poetas cultos que se atrevam a compor décimas, creio que por sua dificuldade, mas em Cuba também por seu estigma rural (Lezama incluiu dois em Paradiso), ainda que sejam em realidade barrocas, e chamadas "espinelas", porque se diz que seu inventor foi Vicente Espinel (1550-1624). Severo deve ter retido em sua

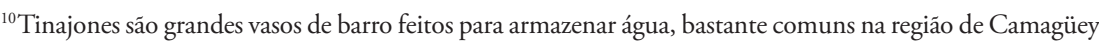
onde nasceu Severo Sarduy. [N. do T.]
} 
memória acústica da infância e juventude cubanas o complicado ritmo dos acentos e das rimas das décimas para poder compô-las tantos anos depois, e apesar da interferência do francês. Severo foi um grande decimista, o melhor da literatura cubana (também foi um bom sonetista). Muitas de suas décimas são humorísticas, de assuntos atrevidos e muito escárnio da morte.

O cubano é também aparente nas obras maiores. Em Pájaros de la playa, por exemplo, as ilhas Canárias do pano de fundo representam Cuba, por razóes históricas, há numerosos descendentes de canários na ilha. São, além disso, ilhas com clima parecido ao do Caribe. Por paronomásia, os canários são também um tipo de pássaros. Ante a morte iminente, Severo oferece nesse último romance uma intensa meditação sobre o ser cubano. A chave desse regresso figurado ao país natal foi Lezama, como sugiro na minha leitura do ensaio "El heredero", que mencionei antes.

Assinado em "Saint Léonard-1988", o texto pretende interpretar e se apropriar de Lezama mediante uma hermenêutica que se vale de esquemas lacanianos, mas que vai além, e faz com que a dimensão lezamiana absorva as ideias do psicanalista, que funcionam apenas como um pretexto, um andaime suplementário e, a meu ver, supérfluo. Porque a proposta de Severo é que Lezama torna possível uma inteligência do cubano implícita no discurso do autor de Paradiso. Basicamente, o primeiro barroco, que deriva da estratégia de convencer a todo custo, promulgada pelo Concílio de Trento, consistente em um incremento do processo de representação, que, segundo Severo, está na origem das ideias de Lezama, dá passagem, no presente, ao Neobarroco, que é sua irrisão: elaborar simultaneamente a verdade e seu duplo burlesco. Este seria o discurso de Paradiso, e de Lezama em geral, que Severo herda. Em Lacan é o "A" maiúsculo e o "a" minúsculo, que para mim não são mais que o típico par retórico que postula algo firme e sua subversão, um modelo de oposição binária previsível e usado até o cansaço. $\mathrm{O}$ exagero, além do primeiro barroco, constitui as "eras imaginárias" de Lezama, construçóes fictícias que saltam por cima da história e da geografia para estabelecer relaçōes significativas entre elementos distantes e díspares. Isto seria o cubano, segundo Severo: uma fusão da hipérbole e do choteo, que viria a ser a assinatura de Lezama e a definição não só do cubano, mas também do americano, que se distancia do barroco europeu.

Lezama é capaz de conseguir semelhante síntese por sua paixão, acrescenta Severo, que quer dizer a consagração total a seu projeto literário, e o sofrimento ao ser submetido, como consequência disso, à indiferença e ao sarcasmo. Severo seria seu herdeiro ao oferecer uma interpretaçáo cabal desse sistema e ao submeter-se à mesma paixão e concomitante deboche - alude ao insulto de Fernández Retamar sem mencionar seu nome. A epígrafe que abre o ensaio, retirada de Heidegger, menciona Hölderlin como poeta do 
sofrimento, e há outra de Benjamin que não é mais que um eco do conhecido ensaio de Freud sobre o inédito, para fundamentar a ideia de que o original é um regresso do conhecido, e que o precursor se instala em um futuro que o herdeiro faz presente mediante sua atividade hermenêutica - interpretação que haveria que entender no sentido musical de tocar uma peça. Mas o balanço de tudo isso é que o cubano é uma síntese da hipérbole e do choteo, com o qual se instala Severo na tradiçấo de Mañach, e assim define sua própria obra, que regressou após um dilatado rodeio, ao tema da identidade própria e nacional.

Uma pergunta, que surge para nós, críticos e historiadores da literatura, de tudo o que se disse acima, é a seguinte. É o epistolário de Severo parte de sua obra? Eu penso que sim, que suas cartas a integram, não só como suplemento no sentido subordinado de elucidação ou chave, mas também porque esses textos são literatura, e ele assim os considerava. Como vocês viram, sobretudo na carta em que diz que se póe um chapéu em forma de caixa de camembert, Severo se autodefinia em suas cartas como faria com seus personagens. Ele mesmo se converte em personagem de suas cartas e, de passagem, me converte também em personagem delas, com os distintos nomes que me dá, inserindo-os depois, cifrados, em suas ficçôes. Este é o segredo dos segredos: Quem sou eu em seus romances? Não vou dizer.

\section{Tradução: Livia Santos de Souza}

Roberto González Echevarría. Doutor pela Universidade de Yale. Professor Titular de Literatura Hispânica e Comparada na Universidade de Yale, onde ocupa uma Cátedra Sterling. Membro da Academia Estadunidense das Artes e das Ciências. Autor de The Voice of the Masters: Writing and Authority in Modern Latin American Literature (1985); La ruta de Severo Sarduy (1986); Myth and Archive: A Theory of Latin American Narrative (1990, 1998), Celestina's Brood: Continuities of the Baroque in Spanish and Latin American Literatures (1993); The Pride of Havana: A History of Cuban Baseball (1999); Crítica práctica, práctica critica (2002), His Love and the Law in Cervantes (2005); Monstros e arquivos: textos criticos reunidos (2014). Editor de The Oxford Book of Latin American Short Stories (1997); Don Quixote: A Case Book (Oxford, 2005); Historia de la literatura hispanoamericana (Cambridge University) (Gredos, 2006). Co-editor de The Cambridge History of Latin American Literature (1996) e de Cuba: un siglo de literatura (1902-2002) (2004). Professor convidado em distintas universidades do mundo e referência indiscutível no campo das literaturas hispânicas e dos estudos de literatura comparada. Obteve o Prêmio Nacional de Humanidades em 2011, que recebeu de mãos do Presidente Barak Obama. E-mail: roberto.echevarria@yale.edu 